\title{
DNA Barcoding and ITS-tufA multi-local molecular phylogeny of nitrophilic alga Prasiola crispa growing on penguin guano at Larsemann Hills, Eastern Antarctica
}

\author{
Sheetal Sharma, Rashmi Ranjan Sutar, Aseema Parida, Felix Bast ${ }^{*}$ \\ Department of Botany, Central University of Punjab, Ghudda, Bathinda, 151401, \\ Punjab, India
}

\begin{abstract}
Antarctica is the coldest and driest continent globally and has always been an exciting habitat to study extremophiles. The study reveals a monostromatic nitrophilic green alga Prasiola crispa (Trebouxiophyceae) growing on Adelie penguin guano at a penguin rockery, Larsemann Hills, Eastern Antarctica. This study is the first report of the barcode of this algal genus from Eastern Antarctica in general and the Larsemann Hills in particular. There are 35 species currently accepted in this genus, while four were reported from Antarctica. The present study relied on morphological diagnoses as well as the phylogenetic inference based on nuclear-encoded ITS gene and plastid-encoded tufA gene for species identification. The study generated phylogenetic reconstruction at the two selected loci for the first time for this species from Antarctica.
\end{abstract}

Key words: molecular phylogeny, taxonomy, Polar region, tufA, ITS, green algae

DOI: $10.5817 / C P R 2021-2-13$

\section{Introduction}

The windiest, coldest and driest continent, the Antarctica, has only $0.32 \%$ of its land ice-free (Chown and Convey 2007). The three biogeographic zones of Antarctica i.e., Sub-Antarctic zone, Maritime Antarctica and Continental Antarctica have different climatic conditions and terrestrial ecosystems (Peter 2010). Studies are been conducted to review the Antarctic climate variability in past years and have reported the warming and climate change on the western side of the Antarctic Peninsula (Bajerski and Wagner 2013). Among them, the shallow subtidal zone of the Western
Antarctic Peninsula dominated by brown algae like Ascoseira mirabilis, Himantothallus grandifolius, Desmarestia anceps while, green algae are very uncommon in this area (Wiencke and Amsler 2012). The most common green algae in Eastern Antarctica are Monostroma hariotii, and earlier reports of macroalga distribution are only available from Windmill Island and Vestfold Hills (Wiencke et al. 2014).

Prasiola is a well-known genus of green algae frequently found in terrestrial, freshwater, and marine habitats (Rindi et al. 1999). Prasiola crispa is a common spe-

Received September 27, 2021, accepted January 3, 2022.

*Corresponding author: F. Bast <felix.bast@gmail.com>

Acknowledgements: This research was supported by Indian Antarctic Mission 2016-17. The study is also supported by DST-SERB Core Research Grant (CRG/2019/005499). 
cies that typically grows on the moist soil around the Antarctic coast, where the bird guano fertilizes the soil. These algae can tolerate repeated freeze cycles in spring and high levels of UV radiation during summer (Jackson and Seppelt 2006). Recently, most researchers used tufA genetic marker for molecular identification and description of new taxa in green seaweeds. The tufA is a plastid marker gene that encodes the elongation factor $\mathrm{Tu}$. The tufA gene is suitable for phylogenetic reconstruction at the genus and species level due to its substitution rate (Choi et al. 2000). The tufA gene is considered as a good candidate for DNA barcoding in freshwater and marine green algae. The exceptions are charophytes, in which this gene has migrated to the nucleus while still preserving a copy in the chloroplast, with consequent problems of paralogy, pseudogenes and other biases (Baldauf and Palmer 1990). Moniz et al. (2014) used tufA gene as a molecular marker for the study of phylogenetic relationship among Prasiola species, from their studies they suggested that the tufA gene has a high potential marker for phylogenetic analysis at a low taxonomic level in Prasiola as compared to the other marker.

Moniz et al. (2012), confirmed that $P$. crispa occurs in Antarctica by comparing the rbcL sequence with the type specimen from the Isle of Skye, Scotland, and also placed $P$. crispa and $P$. antarctica under different lineages. Naw et al. (2002) performed a phylogenetic analysis of freshwater green algae using 18S RNA from Myanmar, morphologically similar to the Enteromorpha (Ulvophyceae) which showed similarity with Prasiola sp. Study of Rindi et al. (2004) focused on morphological and molecular analysis of common species of Prasiolales from Northern Europe based on the $\mathrm{rbcL}$ sequence. Later Rindi et al. (2004) revealed that P. calophylla, P. crispa, P. stipitata are not similar but distinct species.

$P$. crispa was first characterized by Lightfoot in 1777 as Ulva crispa based on the material from the Isle of Skye, Scotland. It is reported as diverse in cold temperate and polar areas, which include all the three biogeography zones of Antarctica (Moniz et al. 2012). The $P$. crispa holds importance due to its survival ability in extreme climatic conditions such as e.g. as repeated freeze/thaw cycles, physiological drought, salinity stress, and high levels of UV radiation (Jacob et al. 1992, Jackson and Seppelt 1997). Its adaptability to the harsh environmental conditions of Antarctica is an evolutionary feature that needs to be investigated further because the genes associated with these adaptive characteristics in $P$. crispa remain unknown (Carvalho et al. 2018). There are nine reports of Prasiola sp. from Antarctica given in Table 1.

\begin{tabular}{cll}
\hline S. No. & Species name & Location \\
\hline $\mathbf{1}$ & Prasiola antarctica & King George Island (South Shetland Islands), Antarctica \\
\hline $\mathbf{2}$ & Prasiola antarctica & Area behind Palmer Station, Antarctica \\
\hline $\mathbf{3}$ & Prasiola antarctica & Amsler Island, Antarctic Peninsula, Antarctica \\
\hline $\mathbf{4}$ & Prasiola crispa & Garwood Valley, McMurdo Dry Valley, Antarctica \\
\hline $\mathbf{5}$ & Prasiola crispa & Upper Garwood Valley, Antarctica \\
\hline $\mathbf{6}$ & Prasiola crispa & Marshall Valley, McMurdo, Antarctica \\
\hline $\mathbf{7}$ & Prasiola crispa & Torgersen Island, Antarctica \\
\hline $\mathbf{8}$ & Prasiola crispa & Cape Royds, Ross Sea, Antarctica \\
\hline $\mathbf{9}$ & Prasiola glacialis & Garwood Valley, McMurdo Dry Valley, Antarctica \\
\hline
\end{tabular}

Table 1. No. of Prasiola sp. reported in Antarctica (Moniz et al. 2012, Fernández-Marín et al. 2019, Garrido-Benavent et al. 2018). 
Molecular systematic assessment of Prasiola had been scanty. This study was conducted for the identification of a sample collected from East Antarctica as part

\section{Materials and Methods}

\section{Study sites and sampling}

The isolates of $P$. crispa were collected from Adelie penguin guano at a penguin rookery (69 $\left.22^{\circ} 43.2^{\prime \prime} \mathrm{S}, 76^{\circ} 09^{\prime} 19.3^{\prime \prime} \mathrm{E}\right)$ of Larsemann Hills, Eastern Antarctica during the $36^{\text {th }}$ Indian Scientific Expedition to Antarctica (ISEA) in 2016-2017. The samples were collected in the vicinity of penguins where a copious amount of

\section{Morphological examination of the algae}

The samples were carefully washed in filtered sterile seawater (FSSW). Photographs were taken using a bright-field microscope (BX53, Olympus, Japan) and a digital SLR camera with Canon macro lens (EOS 60D, Japan). The following morphological characteristics were evaluated: tex- of the Indian Antarctic Mission, the $36^{\text {th }}$ Indian Scientific Expedition to Antarctica (ISEA) in 2016-2017. penguin guano was present. Moist samples were packed in sterile plastic zip-lock bags and stored at $-80^{\circ} \mathrm{C}$ for further studies. The representative specimen was pressed and deposited in the herbarium of Central University of Punjab, Ghudda, Bathinda, India, with voucher number CUPBVOUCHERPrcr-2019-1.

ture, colour, pattern of blade and thallus, height of the thallus, shape, and cell arrangement. Earlier studies on $P$. crispa confirmed the identification. ImageJ software was used for morphological measurements and scale calibration ([1]).

\section{DNA Extraction, Amplification and Sequencing}

The frozen sample's total genomic DNA was extracted using HipurA ${ }^{\mathrm{TM}}$ Algal Genomic extraction kit (HIMEDIA Laboratories Pvt. Ltd., Mumbai). Sample was crushed with silica gel. The concentration of DNA was checked on a Nanodrop spectrophotometer (Thermo scientific $^{\mathrm{TM}}$, Waitham, USA). Plastid-encoded tufA with gene sequence tufA Forward (5'GGNGCNGCNCAAATGGAYGG-3') and tufA Reverse (5'CCTTCNCGAATM GCRAAWCGC-3') (Fama et al. 2002), and nuclear-encoded ITS1 (5'GAGGCAATA ACAGGTCTGTGATGC-3'), ITS2 (5'GC TGCGTTCTTCATCGATGC-3')(White et al. 1990) gene sequences with DreamTaq ${ }^{\mathrm{TM}}$ DNA Polymerase (Applied Biosystems, Foster City, CA, USA) were used in the study. PCR amplification of the extracted DNA was carried out in thermal cyclers (BIO-RAD, California, USA). Reaction profile for tufA primer included the first denaturation at $94^{\circ} \mathrm{C}$ for $4 \mathrm{~min}$., followed by 29 cycles of at $94^{\circ} \mathrm{C}$ for $0.45 \mathrm{~min}$., at $55^{\circ} \mathrm{C}$ for $0.3 \mathrm{~min}$., at $90^{\circ} \mathrm{C}$ for $0.45 \mathrm{~min}$. and a final extension of $72^{\circ} \mathrm{C}$ for $7 \mathrm{~min}$. Reaction procedure for ITS primer was denaturation at $95^{\circ} \mathrm{C}$ for $3 \mathrm{~min}$., followed by 40 cycles at $94^{\circ} \mathrm{C}$ for $0.3 \mathrm{~min}$., at $55^{\circ} \mathrm{C}$ for $0.3 \mathrm{~min}$., at $72^{\circ} \mathrm{C}$ for $1 \mathrm{~min}$. and a final extension at $72^{\circ} \mathrm{C}$ for $7 \mathrm{~min}$. The amplified product was electrophoresed on $1 \%$ agarose gel for $30 \mathrm{~min}$. at $90 \mathrm{~V}$ and visualized with ethidium bromide to determine the length of the amplified template. The purity of the DNA was also tested by using a 
Nanodrop spectrophotometer (Thermo Scientific NanoDrop 2000). To remove the unbound dNTPs and primer present in the amplified sample, the sample was purified using ExoSAP-IT ${ }^{\circledR}$ PCR cleanup kit (USB Corporation, Cleveland, OH, USA). Sequencing of purified PCR product was done using a dideoxy chain termination protocol with a programmable thermal cycler (Veriti, ABI, USA) and ABI BigDye Terminator Cycle Sequencing Ready ${ }^{\circledR}$ Reaction kit v3.1 (Applied Biosystems, Foster City, CA, USA). Then DNA sequencing was carried out by using a 3730xl Genetic Analyzer (Applied Biosystems 3730xl Genetic Analyzer, Foster City, CA, USA).

\section{Multiple sequence alignment and phylogenetic analysis}

The sequenced data were analyzed using Geneious software v 8.0 (Created by Biomatters [2]). The contig was generated by assembling the forward and reverse sequence of the isolate. BLASTn search was used for sequence homology search. All the Prasiola sequences were aligned with other Prasiola sequences available in GenBank (National Center for Biotech-

\section{Results}

\section{Morphological characterization}

Thalli consisted of the monostromatic expanded blade, 17-21 $\mu \mathrm{m}$ in thickness, smooth surface with ribbon-like structure, the large blade is deeply folded (Fig 1a). The larger blades became curled and deeply folded. The habit was observed $3 \mathrm{~cm}$ to $5 \mathrm{~cm}$ in length and $4 \mathrm{~cm}$ to $6 \mathrm{~cm}$ in height. The habit appeared bright green, crispate and branched at the tip (Fig 1a). The thalli are attached to the surface with the help of rhizoid. Rhizoid cells were white, elongated, and narrower than normal cells

\section{Molecular characterization}

The barcodes of $P$. crispa were generated for nuclear-encoded ITS and plastidencoded tufA loci using previously reported primers. The ITS and tufA generated sequences were submitted to GenBank (10407403) and BankIt (2502964) respectively. BLASTn result of the ITS sequence showed $98.20 \%$ sequence similari- nology Information, Bethesda, USA) using the MEGA software followed by manual correction. The terminal ends of aligned sequences were removed to reduce the number of missing sites covering the taxa. The best-fitting nucleotide substitution models were tested using ML Model Test in MEGA.

(Fig 1c). The blade surface was smooth, cells were arranged in regular rows and lacked areolation (Fig 1e). Size of the single cell was 4 to $10 \mu \mathrm{m}$ in length; vegetative cells were rectangular forming groups 4 cells. Generative cells showed aplanospore (Fig 1f), each cell contained a chloroplast, and pyrenoid at the centre (Fig 1d). The morphological results were compared with the morphology reported earlier by Moniz et al. 2012.

ty with Prasiola sp. (KX987989) from King George Island, Antarctica (GarridoBenavent et al. 2017). The tufA gene sequence showed $100 \%$ sequence similarity with Prasiola crispa (MN145934) from Paradise Bay, Antarctic Peninsula (Dubrasquet et al. 2021). 

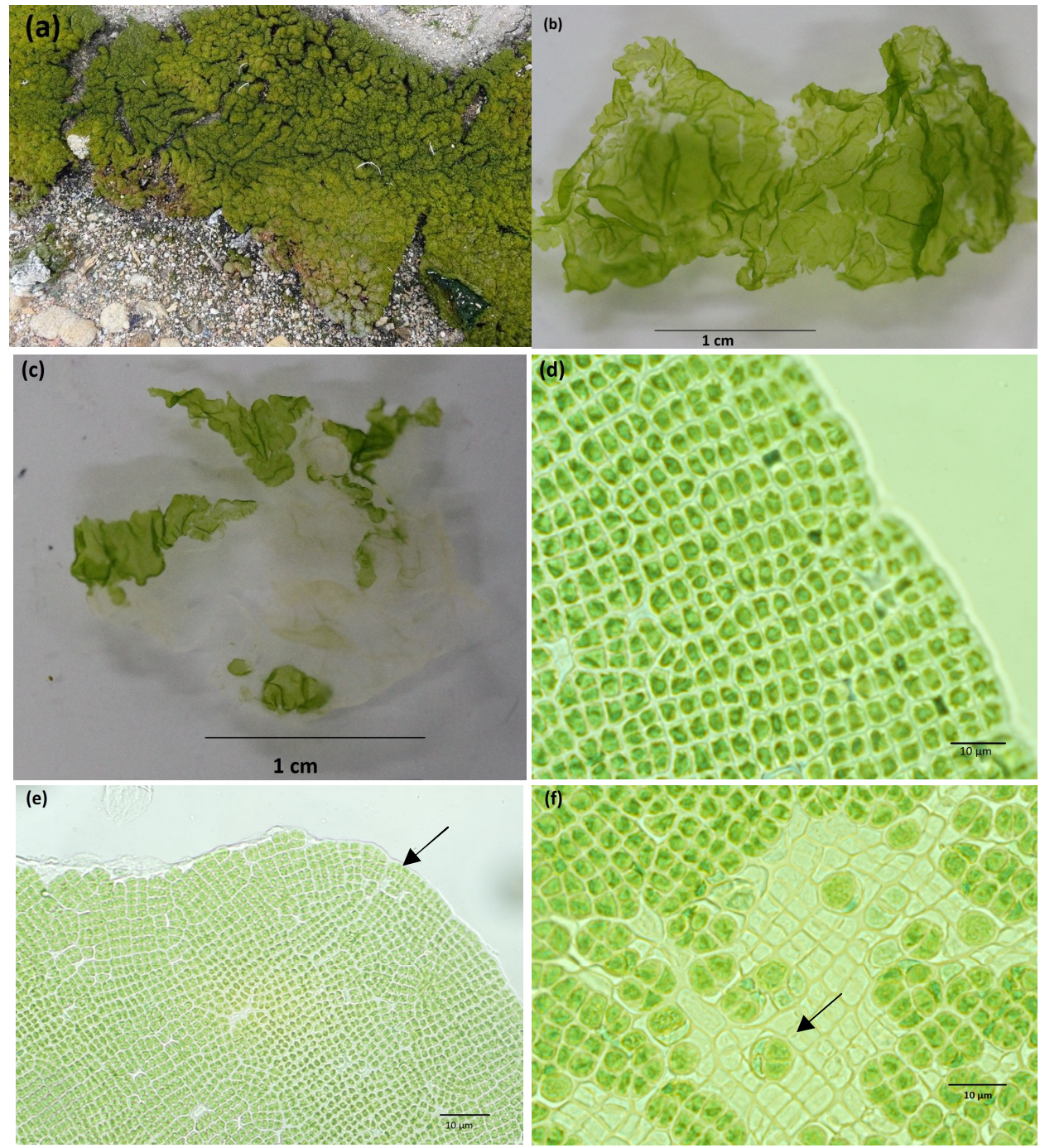

Fig. 1. Morphology of Prasiola crispa. (a) On-site image of Prasiola crispa. Feathers of Adelie penguin is also seen; (b) Structure of thallus; (c) Thallus with rhizoids; (d) Surface view of a thallus (100X) cell with chloroplast; (e) Blade showing little or no areolation; (f) Generative cell showing aplanospores.

\section{Phylogenetic Analysis}

Phylogeny of the tufA sequence with additional 30 accessions of Prasiola was constructed using the Maximum likelihood (ML) method. In this phylogeny, Rosenvingiella radicans and Prasipolopsis were taken as out-groups. For phylogenetic anal- ysis sequences were first aligned by the MUSCLE algorithm in MEGA. The model Tamura 3-parameter (T92) was chosen as the best-fit model per the ML Model Test. Pairwise distance between sequences ranged between 0.00 and 0.211 . In the 
phylogram (Fig. 2), Prasiola crispa specimen (collected from Eastern Antarctica in this study) clustered within a clade with other accessions of Prasiola crispa.

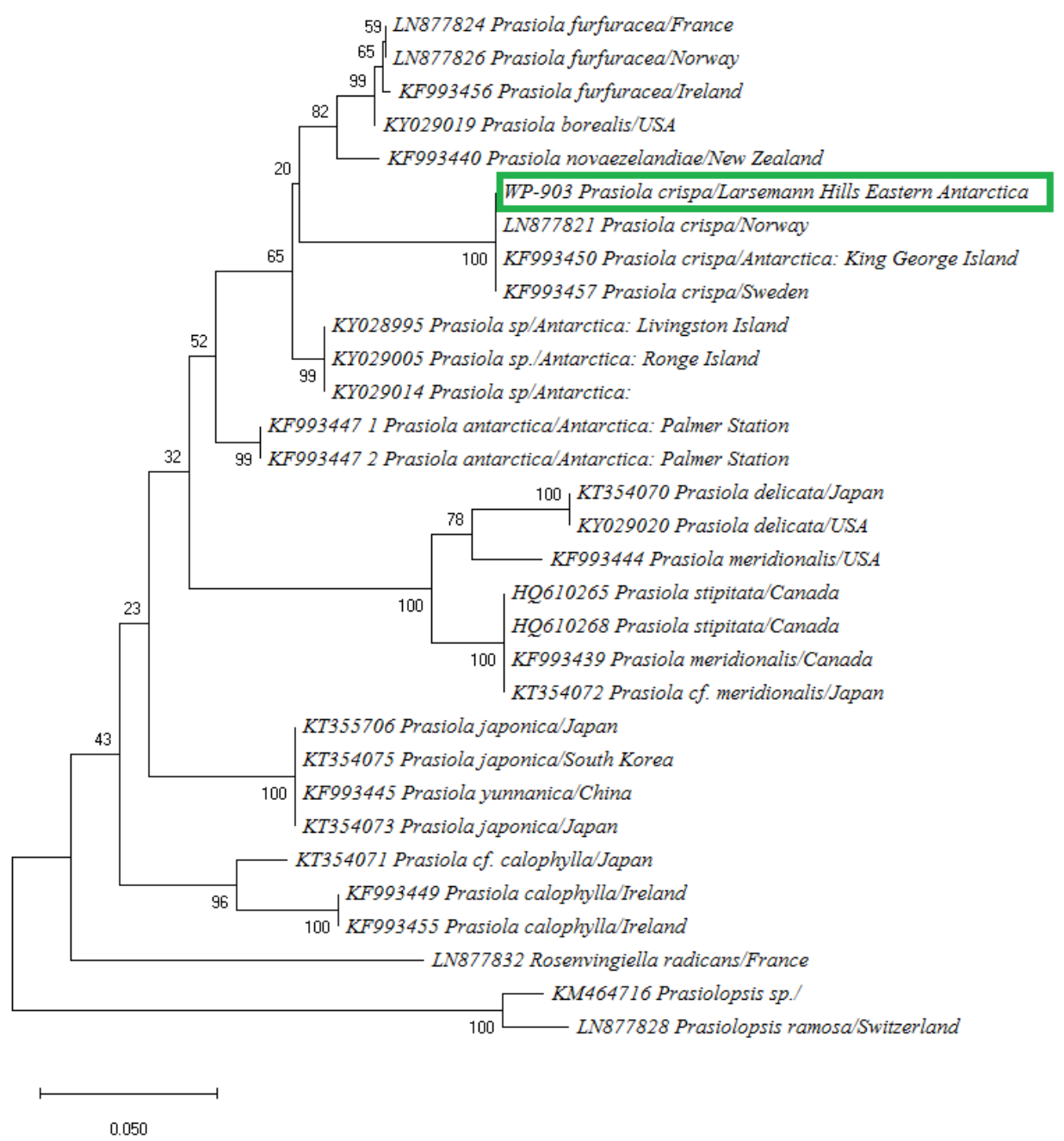

Fig. 2. Phylogenetic tree based on the tufA gene of Prasiola sp. constructed by Bayesian inference and Maximum likelihood methods.

Phylogeny of the ITS sequence with 10 accessions of Prasiola was constructed using the ML method (see Fig 3). In this phylogeny Monostroma kuroshiense (GU062561) was taken as an out-group, as Monostroma is evolutionarily at optimal distance; not too dissimilar or similar to Prasiola.
Pairwise distance between sequences ranged between 0.00 and 1.60. Prasiola crispa (collected from Eastern Antarctica in this study) formed a well-supported distinct group with Prasiola sp. from the King George Island, Antarctica in this study. 


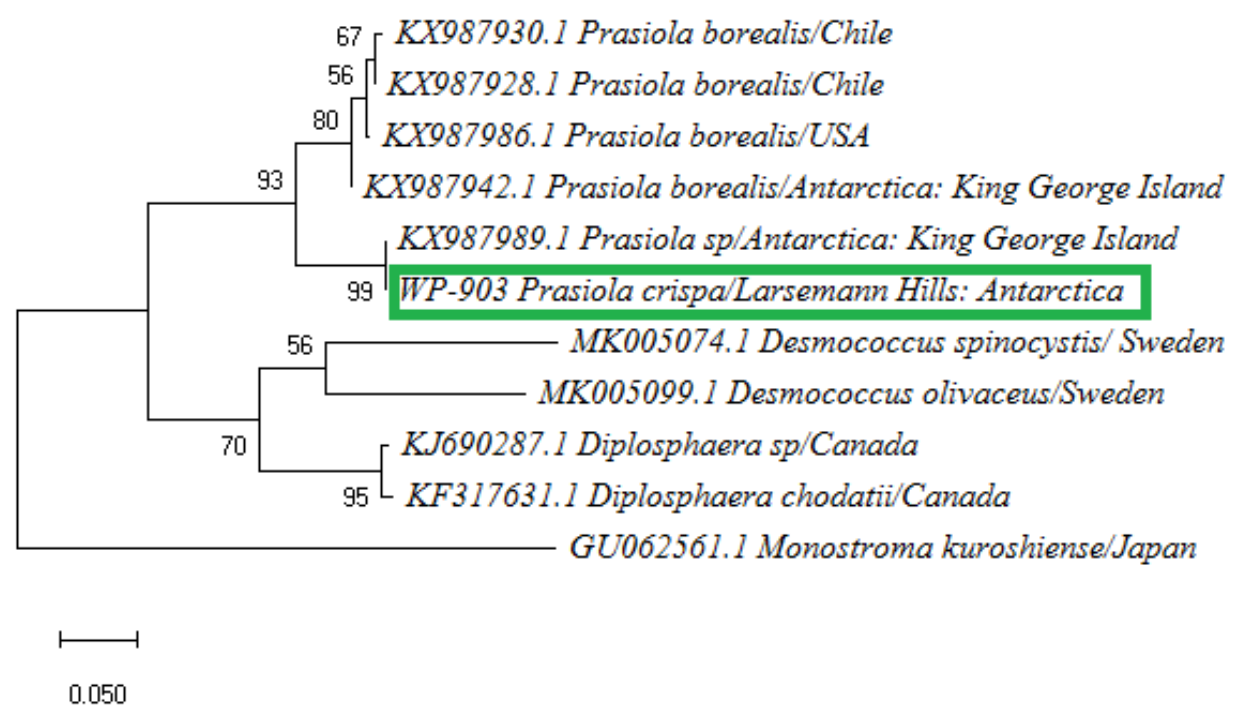

Fig. 3. Phylogenetic tree based on the ITS gene of Prasiola sp. constructed by Bayesian inference and Maximum likelihood methods.

\section{Discussion}

Recent studies have mentioned the greenification of Antarctica due to climate warming, which leads to the growth of moss and green algae growth in the region (Klaus 2021, Antonello 2019, Shibistova et al. 2017, Gray et al. 2021). As compared to brown and red algae, green algae biodiversity is however, studied in Antarctica to a lesser extent. The most important algal primary producer Prasiola crispa is found in abundance in the ice-free region of Antarctica and fertilized by bird guano. In the current study, nitrophilic green alga Prasiola crispa collected from penguin rookeries of Eastern Antarctica was identified by molecular characterization based on nuclear encoded ITS gene and plastidencoded tufA gene as well as the morphological characters. Prasiola crispa is most often reported from the Western Antarctica region (Jacob et al. 1991, Jacob et al. 1992, Moniz et al. 2012). There are a total of four species of Prasiola reported from Antarctica i.e., Prasiola antarctica Kützing, Prasiola crispa (Lightfoot) Kützing,
Prasiola calophylla (Carmichael ex Greville) Kützing and Prasiola glacialis, among which Prasiola glacialis was reported last from Antarctica (Moniz et al. 2012). The Larsemann Hills were reported with homogenous flora and taxonomic analysis revealed around 200 taxa of terrestrial algae (Alekseev et al. 2020). Some studies attempted to provide the biodiversity of the Larsemann Hills, which includes lacustrine and terrestrial diatoms, but reports on terrestrial macroalga algae are very rare (Gupta 2015). Das and Singh (2021) recently reported epiphytic algae on the surface of bryophytes from the Larsemann Hills, Antarctica. This study also provides important insights into the evolutionary legacy of this important nitrophilic terrestrial algal species in Antarctica along with closely related species from elsewhere in the world. To the best of our knowledge, this is the first molecular phylogenetic assessment of Antarctic Prasiola crispa and serves as a baseline for further studies in this line. 


\section{References}

Alekseev, I., Zverev, A. and ABAKumov, E. (2020): Microbial communities in permafrost soils of Larsemann Hills, Eastern Antarctica: Environmental controls and effect of human impact. Microorganisms, 8: 1202. doi: 10.3390/microorganisms 8081202

Antonello, A. (2019): The greening of Antarctica: Assembling an international environment. Oxford University Press, USA. Print ISBN-13: 9780190907174. doi: 10.1093/oso/978019090 7174.001.0001

BAJERSKI, F., WAGNER, D. (2013): Bacterial succession in Antarctic soils of two glacier forefields on Larsemann Hills, East Antarctica. FEMS Microbiology Ecology, 85(1): 128-142. doi: $10.1111 / 1574-6941.12105$

Baldauf, S. L., Palmer, J. D. (1990): Evolutionary transfer of the chloroplast tufA gene to the nucleus. Nature, 344(6263): 262. doi: 10.1038/344262a0

Carvalho, E. L., Maciel, L. F., Macedo, P. E., Dezordi, F. Z., Abreu, M. E., Victoria, F. D. C., Pereira, A. B., Boldo, J. T., Wallau, G. D. L. and Pinto, P.M. (2018): De novo assembly and annotation of the Antarctic alga Prasiola crispa transcriptome. Frontiers in Molecular Biosciences, 4: 89. doi: 10.3389/fmolb.2017.00089

ChOI, K. R., RoH, K., KIM, J. and SiM, W. (2000): Genomic cloning and characterization of mitochondrial elongation factor $\mathrm{Tu}(\mathrm{EF}-\mathrm{Tu})$ gene (tufM) from maize (Zea mays L.). Gene, 257(2): 233-42. doi: 10.1016/s0378-1119(00)00404-2

Chown, S. L., Convey, P. (2007): Spatial and temporal variability across life's hierarchies in the terrestrial Antarctic. Philosophical Transactions of the Royal Society B: Biological Sciences, 362(1488): 2307-2331. doi: 10.1098/rstb._2006.1949

DAS, S. K., Singh, D. (2021): Epiphytic algae on the bryophytes of Larsemann Hills, East Antarctica. National Academy Science Letters, 44(2): 161-165. doi: 10.1007/s40009-02000947-7

Dubrasquet, H., Garrido, I., Bruning, P., Reyes, J. and Guillemin, M. L. (2021): Building-up knowledge on green marine macroalgae diversity in the Western Antarctic Peninsula: Data from two molecular markers reveals numerous species with amphipolar distribution. Cryptogamie Algologie, 42(2): 21-37. doi: 10.5252/cryptogamie-algologie2021v42a2

Fernández-Marín, B., López-Pozo, M., Perera-Castro, A. V., Arzac, M. I., SÁenzCeniceros, A., Colesie, C., De los Ríos, A., Sancho, L.G., Pintado, A., Laza, J. M. and PÉREZ-OrTega, S. (2019): Symbiosis at its limits: ecophysiological consequences of lichenization in the genus Prasiola in Antarctica. Annals of Botany, 124(7): 1211-1226. doi: $10.1093 / \mathrm{aob} / \mathrm{mcz} 149$

Garrido-Benavent, I., de los Ríos, A., Fernández-Mendoza, F. and Pérez-Ortega, S. (2018): No need for stepping stones: Direct, joint dispersal of the lichen-forming fungus Mastodia tessellata (Ascomycota) and its photobiont explains their bipolar distribution. Journal of Biogeography, 45(1): 213-224. doi: 10.1111/jbi.13105

Garrido-Benavent, I., Pérez-Ortega, S. and de los Ríos, A. (2017): From Alaska to Antarctica: Species boundaries and genetic diversity of Prasiola (Trebouxiophyceae), a foliose chlorophyte associated with the bipolar lichen- forming fungus Mastodiatess ellata. Molecular Phylogenetics and Evolution, 107: 117-131. doi: 10.1016/j.ympev.2016.10.013

Gray, A., Krolikowski, M., Fretwell, P., Convey, P., Peck, L., Mendelova, M., Smith, A. G. and DAVEY, M. (2021): Remote sensing phenology of Antarctic green and red snow algae using WorldView satellites. Frontiers in Plant Science, 12: 877. doi: 10.3389/fpls.2021.671981

GuPTA, P. (2015): Biodiversity of Larsemann Hills, Antarctica, Climate Change, 1(3): 174-183.

JACKSON, A., SEPPELT, R. (2006): The accumulation of proline in Prasiola crispa during winter in Antarctica. Physiologia Plantarum, 94: 25-30. doi: 10.1111/j.1399-3054.1995.tb00 779.x

JACKSON, A. E., SEPPELT, R. D. (1997): Physiological adaptations to freezing and UV radiation exposure in Prasiola crispa, an Antarctic terrestrial alga. In: B. Battaglia, J. Valencia, and D. W. H. Walton (eds.): Antarctic Communities: Species, Structure, and Survival, (Cambridge: University Press), pp. 226-233. 
Jacob, A., Kirst, G. O., Wiencke, C. and Lehmann, H. (1991): Physiological responses of the Antarctic green alga Prasiola crispa ssp. antarctica to salinity stress. Journal of Plant Physiology, 139(1): 57-62.

JacoB, A., Wiencke, C., Lehmann, H. and Kirst, G. O. (1992): Physiology and ultrastructure of desiccation in the green alga Prasiola crispa from Antarctica. Botanica Marina, 35: 297-303. doi: 10.1515/botm.1992.35.4.297

KLaus, D. (2021): The Greening of Antarctica: Assembling an international environment, by Alessandro Antonello, The English Historical Review, 136(579): 461-463. doi: 10.1093/oso/ 9780190907174.001.0001

Moniz, M. B., GuiRY, M. D. and Rindi, F. (2014): Tuf A phylogeny and species boundaries in the green algal order Prasiolales (Trebouxiophyceae, Chlorophyta). Phycologia, 53(4): 396-406. doi: $10.2216 / 13-233.1$

Moniz, M. B., Rindi, F., Novis, P. M., Broady, P. A. and Guiry, M. D. (2012): Molecular phylogeny of Antarctica Prasiola (Prasiolales, Trebouxiophyceae) Reveals Extensive Cryptic Diversity. Journal of Phycology, 48(4): 940-955. doi: 10.1111/j.1529-8817.2012.01172.x

NAw, M. W. D., Hara, Y. (2002): Morphology and molecular phylogeny of Prasiola sp. (Prasiolales, Chlorophyta) from Myanmar. Phycological Research, 50(3): 175-182. doi: 10.1046/ j.1440-1835.2002.00271.x

Peter, C. (2010): Terrestrial biodiversity in Antarctica-Recent advances and future challenges. Polar Science, 4(2): 135-147. doi: 10.1016/j.polar.2010.03.003

Rindi, F., Guiry, M. D., BARBiero, R. P. and Cinelli, F. (1999): The marine and terrestrial Prasiolales (Chlorophyta) of Galway City, Ireland: a morphological and ecological study. Journal of Phycology, 35(3): 469-482. doi: 10.1046/ j.1529-8817.1999.3530469.x

Rindi, F., McIvor, L. and GUIRY, M. D. (2004): The Prasiolales (Chlorophyta) of Atlantic Europe: An assessment based on morphological, molecular, and ecological data, including the characterization of Rosenvingiella radicans (KÜTZING) comb. nov. Journal of Phycology, 40(5): 977-997. doi: 10.1111/j.1529-8817.2004.04012.x

Shibistova, O., Boy, J., Godoy, R., Boy, D., McCulloch, R., Mikutta, R. and Guggenberger, G. (2017): Greening boosts soil formation and soil organic matter accumulation in Maritime Antarctica. https://eprints.dbges.de/id/eprint/1775

Wiencke, C., Amsler, C. D. (2012): Seaweeds and Their Communities in Polar Regions. In: C. Wiencke, K. Bischof (eds): Seaweed Biology. Ecological Studies (Analysis and Synthesis), 219: 265-291. Springer, Berlin, Heidelberg. doi: 10.1007/978-3-642-28451-9_13

Wiencke, C., Amsler, C. D. and Clayton, M. N. (2014): Macroalgae. In: C. De Broyer, P. Koubbi, H. Griffiths, B. Raymond, C. Udekem d*Acoz (eds.): Biogeographic Atlas of the Southern Ocean., Biogeographic Atlas of the Southern Ocean., Cambridge, Scientific Committee on Antarctic Research, 8 p., ISBN: 978-0-948277-28-3

\section{Web sources / Other sources}

[1] ImageJ software http://rsbweb.nih.gov/ij/

[2] Geneious software v 8.0 (Created by Biomatters) http://www.geneious.com 